\title{
Fresh Forage and Solin Supplementation on Conjugated Linoleic Acid Levels in Plasma and Milk
}

\author{
A. T. Ward, ${ }^{\star}$ K. M. Wittenberg, ${ }^{*}$ H. M. Froebe* R. Przybylski, $\dagger$ and L. Malcolmson $\dagger$ \\ *Department of Animal Science \\ †Department of Human Nutritional Sciences \\ University of Manitoba, Winnipeg, Manitoba, Canada, R3T 2N2
}

\section{ABSTRACT}

Two experiments were run concurrently to determine the effect of fresh forage consumption on the production and proportions of plasma and milk fat vaccenic acid (VA), conjugated linoleic acid (CLA), and linolenic acid in dairy cattle. In experiment 1 , the cows consumed 50 , 65 , and $80 \%$ of their feed intake as pasture with the remainder of intake as a barley-based concentrate. The proportion of VA in milk fatty acids increased $12 \%$ when pasture intake increased from 50 to $65 \%$ of total dry matter intake and VA, CLA, and linolenic acid proportions increased 26,18 , and $27 \%$, respectively, as pasture increased from 65 to $80 \%$ of dietary intake. In experiment 2, fresh forage was compared to conserved hay (cut from the same pasture the previous summer) to determine the effect on plasma and milk fat VA, CLA, and linolenic acid. Also, the effect of crushed solin seed (a flax cultivar that is high in linoleic acid) supplementation to the fresh forage diet was determined. Fresh forage compared to conserved hay in the diet, increased the proportion of CLA in the plasma very low density lipoproteins (VLDL) fraction by $71 \%$ but had no effect on linolenic acid. Supplementation of the fresh forage diet with a linoleic acid source increased VA and CLA in the plasma VLDL fraction 25 and 58\% and slightly decreased the proportion of linolenic acid. Fresh forage, compared to conserved hay, increased milk fat VA and CLA proportions by 22 and $15 \%$. Supplementing the fresh forage diet with linoleic acid from crushed solin seed further increased milk fat VA and CLA proportions 41 and $25 \%$. Solin supplementation in a lactation diet is a superior method to increase CLA levels in milk fat than feeding fresh forage alone.

(Key words: linoleic acid, solin, milk fat, very low density lipoproteins, CLA)

Abbreviation key: CLA = conjugated linoleic acid, FAME = fatty acid methyl esters, FF = fresh forage,

Received May 28, 2002.

Accepted October 14, 2002.

Corresponding author: Karin Wittenberg; e-mail: km_wittenberg @umanitoba.ca.
FFT $=$ fresh forage plus tallow diet, FFS $=$ fresh forage plus solin diet, HT = hay diet, LHDL = low and high density lipoproteins, VA = vaccenic acid, $\mathbf{V L D L}=$ very low density lipoproteins.

\section{INTRODUCTION}

The dietary fatty acid content of the lactating dairy cow has an effect on fatty acid composition of the milk fat (Grummer, 1991). Supplementing the lactation diet with linoleic acid (Kelly et al., 1998a) or pasturing dairy cows (Kelly et al., 1998b; Dhiman et al., 1999) are two methods to increase conjugated linoleic acid (CLA) in milk fat. The production of CLA occurs in the rumen by incomplete biohydrogenation of linoleic acid to stearic acid (Harfoot and Hazelwood, 1988). Milk CLA is derived from escaped rumen CLA and from endogenous synthesis of CLA in the mammary gland from vaccenic acid (VA; Corl et al., 1998; Griinari et al., 2000), an intermediate in the ruminal biohydrogenation of polyunsaturated fatty acids (Harfoot and Hazelwood, 1988). Linolenic acid, the predominate fatty acid in forage, does not form CLA in the bovine rumen (Griinari and Bauman, 1999). Linolenic acid, however, can form VA that can be desaturated in the mammary gland by the epithelial tissue 9-desaturase enzyme to form CLA (Griinari et al., 2000).

Dhiman et al. (1999) increased the amount of grasslegume pasture consumed by dairy cows from $1 / 3$ to full pasture, replacing a diet based on alfalfa hay and high moisture ear corn. The CLA increased from 0.8 to $2.2 \%$ of total milk fatty acids, but milk production and DM intake decreased. Fresh cut forage (FF) mixed in a TMR may increase CLA milk fat levels, similar to pasture feeding, without the decreased DM intake. Increasing the amount of linoleic acid, the rumen precursor of CLA, to animals consuming $\mathrm{FF}$ should increase the rumen level of VA and CLA and subsequently increase the level of plasma and milk VA and CLA from rumen escape of these fatty acids. The levels of CLA should be above the amount produced solely by FF consumption.

Solin (linola) is a new cultivar of flax, registered for production in Canada in 1999, contains approximately 
$28 \%$ linoleic acid, which represents $70 \%$ of the fatty acids in the oil (Dribnenski et al., 1999). Supplementation of solin in a FF based TMR lactation diet, therefore, would give the dairy cow a readily available source of linoleic acid.

The objectives of the experiments were: 1$)$ to determine the effect of increasing levels of grass pasture on VA and CLA content of milk fat, 2) to determine the effects of a fresh forage based (FF) TMR versus conserved hay on VA and CLA levels in plasma and milk, and 3) to determine the effect of solin (high linoleic acid source) plus FF versus FF only on plasma and milk VA and CLA levels.

\section{MATERIALS AND METHODS}

\section{Experiment 1}

Animals, feeding, and milk collection. The care and handling of the cows used in the experiments conformed to the guidelines established by the Canadian Council on Animal Care (1993).

Fifteen primaparous Holstein lactating cows were selected for each of two completely randomized trials. In each trial cows were balanced according to milk production $(33.1 \pm 5.0 \mathrm{~kg} / \mathrm{d})$, stage of lactation $(168 \pm 89 \mathrm{DIM})$, and BW (552 $\pm 49 \mathrm{~kg})$. After balancing, cows were randomly assigned to one of three dietary treatment groups for periods of 23 (Trial 1) and 25 (Trial 2) d. The treatments consisted of feeding three different levels of concentrate to the three groups of cows, resulting in three different levels of pasture intake. Cows were rotationally grazed on pasture except for $2 \mathrm{~h}$ during morning and evening milking at which time the cows received concentrate at 20,35 , or $50 \%$ of pre-trial determined feed intakes (DM basis). Initial feed intakes used to calculate supplementation rates were determined by measuring the daily amount of a TMR (DM basis), composed of corn and alfalfa silage and a concentrate mixture, consumed per cow over a 5-d period immediately prior to adjusting the cattle to pasture. The concentrate consisted of a steam-rolled barley-based mixture (NEL $1.95 \mathrm{Mcal} / \mathrm{kg}, \mathrm{CP} 17.2 \%$ ) and a pelleted supplement $\left(\mathrm{NE}_{\mathrm{L}} 1.81 \mathrm{Mcal} / \mathrm{kg}, \mathrm{CP} 31.6 \%\right)$. The pasture forage, concentrate, and supplement proximate analyses for trial 1 and 2 are presented in Table 1 . The pasture consisted primarily of orchard grass (Dactylis glomerata) with small amounts of timothy (Phleum pratense), smooth bromegrass (Bromus inermis), tall fescue (Festuca arundinacea), and birdsfoot trefoil (Lotus corniculatus). Fresh water was available at all times. The pasture was divided into nine paddocks of approximately 0.4 ha each. These were each subdivided into three equal sized paddocks. The cows grazed the first third of paddock one on $d 1$, the first two thirds for the next day, and then the whole paddock the following day. This continued from paddocks one to nine, and then the cows rotated at the first paddock again.

Duplicate sub-samples of milk were collected the last $2 \mathrm{~d}$ of each trial period, at the regular milking time, over a $48 \mathrm{~h}$ period (four consecutive milking times). One set of milk samples was preserved with bronopol-B2 and stored at $4^{\circ} \mathrm{C}$ until analyzed by an accredited laboratory (\#125) ISO Guide 25, for fat, protein, and SNF (MilkO-Scan 303AB, Foss Electric, Hillerød, Denmark), the other set was frozen and stored at $-20^{\circ} \mathrm{C}$ until analyzed for lipids.

\section{Experiment 2}

Dietary treatment and animals. The three dietary treatments consisted of hay plus concentrate, canola meal, and tallow (HT), fresh cut forage plus concentrate, canola meal, and tallow (FFT), and fresh cut forage, plus concentrate, and solin crushed seed (FFS; Table 2). The FFT and FFS diets were designed to mimic the diet of cows consuming grass pasture by feeding green chop forage. The fresh cut forage was chopped and mixed into a TMR so that the fresh forage and hay would be presented to the cow in a similar manner, without the confounding affects of grazing. The fresh forage was cut from the same field used to make grass hay the previous year. Either a combination of Alifet (Alifet USA, Inc., Cincinnati, Ohio) and tallow plus canola meal or whole crushed solin seed were used as sources of supplemental protein and fat. The forage:concentrate ratio was 59:41.

Twelve multiparous Holstein cows were assigned to one of the three dietary treatments in each period of the $3 \times 3$ Latin square experiment. Each period consisted of $19 \mathrm{~d}$, which included a 14-d adjustment period followed by a 5-d sampling period. Cows were housed in tie stalls with continuous access to water. Cows were fed the TMR once daily such that orts were 5 to $10 \%$ of intake (as-fed basis). Cow BW were recorded on 2 consecutive $\mathrm{d}$ at the start of the trial and at the end of each experimental period.

The calculated $\mathrm{NE}_{\mathrm{L}}$ for the HT, FFT, and FFS diets were $1.65,1.62$, and $1.64 \mathrm{Mcal} / \mathrm{kg}$, respectively, based on $\mathrm{NE}_{\mathrm{L}}$ values of nutrients composing the diet. The average NDF and $\mathrm{ADF}$ (DM basis) over the three experimental periods were $59.3 \pm 2.1$ and $36.9 \pm 1.8 \%$ for the fresh cut grass and for the hay were $60.8 \pm 1.8$ and 36.8 $\pm 2.3 \%$.

Sample collection and processing. The TMR offered and orts were measured on a daily basis. Feed and orts samples were taken once weekly during the $14 \mathrm{~d}$ adjustment period and daily during the sampling phase of each of the experimental periods. Samples 
Table 1. Proximate analysis and fatty acid profile, as $\%$ of total fatty acids, of pasture forage and concentrates (Experiment 1).

\begin{tabular}{lccc}
\hline & \multicolumn{3}{c}{ Analysis of diet constituents } \\
\cline { 2 - 4 } & Pasture forage & Grain mix ${ }^{1}$ & Supplement $^{2}$ \\
\hline $\mathrm{DM}$ & 18.7 & 92.7 & 89.4 \\
(\% of DM) & & & \\
$\mathrm{CP}$ & 11.9 & 17.2 & 31.6 \\
$\mathrm{ADF}$ & 37.8 & 8.7 & 11.5 \\
$\mathrm{NDF}$ & 59.8 & 19.0 & 30.0 \\
Calcium & 0.31 & 0.89 & 2.73 \\
Phosphorus & 0.17 & 0.26 & 0.32 \\
Fatty acids (\% of total fatty acids) & & & \\
$\mathrm{C}_{14: 0}$ & 0.51 & 1.76 & 1.99 \\
$\mathrm{C}_{15: 0}$ & 0.17 & 0.19 & 0.18 \\
$\mathrm{C}_{16: 0}$ & 16.90 & 34.34 & 22.07 \\
$\mathrm{C}_{16: 1}$ & 1.30 & 2.19 & 0.34 \\
$\mathrm{C}_{17: 0}$ & 0.21 & 0.48 & 3.90 \\
$\mathrm{C}_{18: 0}$ & 1.26 & 35.14 & 35.58 \\
$\mathrm{C}_{18: 1}$ & 1.96 & 3.00 & 27.62 \\
$\mathrm{C}_{18: 2}$ & 15.18 & 0.35 & 1.08 \\
$\mathrm{C}_{18: 3}$ & 55.93 & \multicolumn{3}{c}{. } & \\
\hline
\end{tabular}

${ }^{1}$ The grain mix contained (\% DM basis): steam rolled barley 49.7; wheat shorts 12.0 ; steam rolled corn 11.0; canola meal 7.0; soybean meal 5.5; corn distiller's grain 2.0; blood meal 1.8; vegetable oil 1.0; tallow 1.0 ; limestone 0.7 ; wheat 6.0 ; Dynamate ${ }^{\mathrm{TM}} 0.8$, salt 0.7 ; dicalcium phosphate 0.7 ; mineral, vitamin premix 0.2 .

${ }^{2}$ The supplement contained (\% DM basis): distiller's dried grain 69.7; fish meal 14.0; limestone 5.0; sodium bicarbonate 5.0; soybean meal 3.0; beet molasses 3.0; niacin 0.3 .

were stored at $-20^{\circ} \mathrm{C}$ until analyzed. Feed and ort samples were dried in a forced-air oven at $60^{\circ} \mathrm{C}$ for $48 \mathrm{~h}$. The dry weights were used to determine feed intake.
Milk yields were determined during the sampling phase of each experimental period. Duplicate sub-samples of milk were collected at each milking over a $48 \mathrm{~h}$

Table 2. Diet ingredient composition, nutrient analysis and fatty acid profile as percentage of total dietary fatty acids for Experiment 2.

\begin{tabular}{|c|c|c|c|c|}
\hline \multirow[b]{2}{*}{ Ingredient } & \multicolumn{3}{|c|}{$\operatorname{Diets}^{1}$} & \multirow[b]{2}{*}{$\mathrm{SE}$} \\
\hline & HT & FFT & FFS & \\
\hline Fresh grass forage & - & 59.2 & 59.5 & - \\
\hline Grass hay & 57.1 & - & - & - \\
\hline Concentrate & 30.6 & 30.9 & 30.5 & - \\
\hline Solin & - & - & 10.2 & - \\
\hline Canola meal & 8.9 & 7.8 & - & - \\
\hline Tallow & 1.1 & 1.1 & - & - \\
\hline Alifet ${ }^{\mathrm{TM}}{ }^{2}$ & 2.9 & 2.1 & - & - \\
\hline Dry matter, $\%$ & $86.8^{\mathrm{a}}$ & $31.8^{\mathrm{b}}$ & $33.1^{\mathrm{b}}$ & - \\
\hline \multicolumn{5}{|l|}{ TMR analyses } \\
\hline Protein, \% DM & 15.3 & 16.4 & 15.9 & - \\
\hline Ether extract, \% DM & 5.8 & 5.5 & 5.3 & - \\
\hline $\mathrm{ADF}, \% \mathrm{DM}$ & 27.2 & 27.7 & 28.5 & - \\
\hline $\mathrm{NDF}, \% \mathrm{DM}$ & 47.5 & 45.7 & 48.2 & - \\
\hline \multicolumn{5}{|c|}{ Fatty acids (\% of total fatty acids) } \\
\hline $\mathrm{C}_{14: 0}$ & $2.13^{\mathrm{a}}$ & $2.12^{\mathrm{a}}$ & $0.37^{\mathrm{b}}$ & 0.10 \\
\hline $\mathrm{C}_{16: 0}$ & $24.06^{\mathrm{a}}$ & $23.07^{\mathrm{a}}$ & $11.71^{\mathrm{b}}$ & 0.44 \\
\hline $\mathrm{C}_{18: 0}$ & $29.41^{\mathrm{a}}$ & $30.02^{\mathrm{a}}$ & $5.34^{\mathrm{b}}$ & 1.75 \\
\hline $\mathrm{C}_{18: 1}$ & 13.84 & 13.07 & 13.00 & 1.16 \\
\hline $\mathrm{C}_{18: 2}$ & $10.90^{\mathrm{a}}$ & $10.51^{\mathrm{a}}$ & $53.54^{\mathrm{b}}$ & 1.35 \\
\hline $\mathrm{C}_{18: 3}$ & $6.89^{\mathrm{b}}$ & $8.40^{\mathrm{b}}$ & $12.20^{\mathrm{a}}$ & 1.39 \\
\hline
\end{tabular}

${ }^{\mathrm{a}, \mathrm{b}}$ Different letters within rows between columns indicate treatment differences $(P<0.05)$.

${ }^{1}$ The diets were composited by week $(\mathrm{n}=9)$.

${ }^{2}$ Alifet is a tallow-starch based product sold as an energy source for dairy cattle (Alifet USA, Inc., Cincinnati, Ohio). 
period on $\mathrm{d} 18$ and 19. One set of milk samples was preserved with bronopol-B2 and stored at $4^{\circ} \mathrm{C}$ until analyzed as in experiment 1 . The second set was frozen and kept at $-20^{\circ} \mathrm{C}$ until analyzed for fatty acids, including the CLA isomers.

Blood samples were collected during the sampling phase of each period at 0900,1500 , and $2100 \mathrm{~h}$ on $\mathrm{d} 16$ and at $0300 \mathrm{~h}$ on $\mathrm{d} 17$. The blood was collected from the tail vein of the cows using 10 -ml evacuated containers (Becton Dickinson and Co., Franklin Lakes, NJ) with sodium heparin as anticoagulant. Sodium fluoride was added to inhibit enzyme activity. Plasma was collected by centrifugation $(3000 \times g)$ and stored at $-20^{\circ} \mathrm{C}$ until analyzed. Plasma samples from the four collection times were composited by cow in each period and a $2.4 \mathrm{ml}$ subsample was combined with $0.8 \mathrm{ml}$ sodium chloride solution (16.42 $\mathrm{g} / \mathrm{L}$ of water) and centrifuged $(110,000 \times g)$ for $18 \mathrm{~h}$ to separate the lipoprotein fractions (Christie, 1981). The chylomicron and very low density lipoprotein (VLDL) fractions were collected in the top $1 \mathrm{ml}$ of the separated plasma and the low and high density lipoproteins (LHDL) in the bottom $1.2 \mathrm{ml}$. The middle $1 \mathrm{ml}$ was discarded.

\section{Analysis of Samples Collected}

Feed samples were ground through a 1-mm screen (Cyclotec 1093 mill, Tecator, Sweden), composited by week, and analyzed for DM, CP, calcium, and phosphorus (AOAC, 1990). The samples were analyzed for NDF and ADF using the Ankom filter bag technique (Ankom Co. Publ. \#103, 1993, Fairport, NY) based on the methods of Goering and Van Soest (1970).

Lipids in feed $(0.5 \mathrm{~g})$, milk $(1 \mathrm{ml})$ from experiments 1 and 2 , and plasma fractions from experiment 2 were analyzed using a modified procedure for total lipids in human milk (Folch et al., 1957) as described by Jensen et al. (1991) except that $1 \mathrm{ml}$ of an internal standard (1 $\mathrm{mg} / \mathrm{ml}$, of methyl 10-heptadecenoate [C17:1]; Nu-ChekPrep, Inc., Elysian, MN, dissolved in chloroform /methanol, 2:1, v/v) was added to each sample before extraction, and the extracted lipids were evaporated under nitrogen and then dissolved in $1 \mathrm{ml}$ of iso-octane. The lipids were esterified in capped screw top tubes, containing Teflon cap liners, with $6 \mathrm{ml}$ of $0.5 \mathrm{~N}$ sodium methoxide and heated at $50^{\circ} \mathrm{C}$ for $10 \mathrm{~min}$ (Christie, 1981; Kramer et al., 1997). The fatty acid methyl esters (FAME) were then cooled to room temperature, and 2 $\mathrm{ml}$ of iso-octane and $3 \mathrm{ml}$ of $10 \%$ acetic acid were added. The tubes were immediately recapped to prevent evaporation of the short chain fatty acids. The FAME were centrifuged $(2000 \times \mathrm{g})$ for $10 \mathrm{~min}$, and a portion of the top layer removed and placed in sealed gas chromatography vials and kept at $-20^{\circ} \mathrm{C}$ until analyzed. The VLDL frac- tion was concentrated by evaporation under a stream of nitrogen.

The FAME were analyzed in a GLC (Hewlett Packard Co., Model 5890) fitted with a flame ionization detector. Data was collected automatically, and fatty acids were identified by comparison to a general standard containing 32 FAME (GLC reference standard-461, NuChek-Prep, Inc., Elysian, MN) using the computer program Chrom Perfect for Windows (Justice Inovations, Mountain View, CA). Retention times of CLA isomers and VA were checked by co-elution of samples with commercially prepared (Matreya, Inc., Pleasant Gap, PA) methyl ester standards of these fatty acids. The presence of other trans isomers was not precluded, however it is well established that the trans-11 isomer is the predominant isomer in milk (Wolff et al., 1998). Peak area and percent of individual fatty acids were quantified by comparing the peak areas of the samples corrected for losses by internal standard to the area of external standards (GLC reference standards, NuChek-Prep, Inc., Elysian, MN). Sample methyl esters in iso-octane were injected through a split-splitless injector onto a SP-2560 fused silica capillary column (100 $\times 0.25 \mathrm{~mm}$ i.d. $\times 0.2 \mu \mathrm{m}$ film thickness; Supelco Inc., Bellefonte, PA) using automatic injection. Hydrogen was the carrier gas and was set at 40 psi. The column parameters were as follows: initial column temperature of $70^{\circ} \mathrm{C}$ was maintained for $2 \mathrm{~min}$; the temperature was then programmed to increase $15^{\circ} \mathrm{C}$ per min to $155^{\circ} \mathrm{C}$. This temperature was maintained for $25 \mathrm{~min}$, and then increased $3^{\circ} \mathrm{C}$ per min to $215^{\circ} \mathrm{C}$ and remained at this temperature for $8 \mathrm{~min}$. The total time for each chromatographic separation was set at $61 \mathrm{~min}$.

\section{Calculations and Statistical Analysis}

The calculation of endogenous CLA production in the mammary gland assumed that the CLA and VA are absorbed into the mammary gland in the same ratio as is found in the VLDL fraction of the plasma:

$\%$ CLA in milk fatty acids from plasma $=$ $\%$ VA in milk fatty acid/\% VA in plasma VLDL $\times \%$ CLA in plasma VLDL

$\%$ endogenous CLA $=\%$ CLA in milk fatty acids $\%$ CLA in milk fatty acids from plasma/ $\%$ CLA in milk fatty acids

The feed analyses, milk fatty acid, and production data from experiment 1 were analyzed as replicated random blocks using the general linear models procedure of SAS (1996). Performance data and plasma VLDL, HLDL, and milk fatty acid data from experiment 
Table 3. Performance variables of cows consuming increasing percent of DMI as forage (Experiment 1).

\begin{tabular}{lcccc}
\hline & \multicolumn{3}{c}{ Forage (consumed \% of DMI) } & \\
\cline { 2 - 4 } Item & $50 \%$ & $65 \%$ & $80 \%$ & SE \\
\hline Milk yield, kg/d & $30.35^{\mathrm{a}}$ & $26.18^{\mathrm{a}}$ & $21.93^{\mathrm{b}}$ & 1.47 \\
Milk fat \% & 3.42 & 3.91 & 3.71 & 0.15 \\
Milk protein \% & 3.37 & 3.22 & 3.14 & 0.09 \\
Milk SNF \% & 8.94 & 8.82 & 8.62 & 0.10 \\
\hline
\end{tabular}

${ }^{\mathrm{a}, \mathrm{b}}$ Different letters within rows indicate treatment differences $(P$ $<0.05 ; \mathrm{n}=15)$.

2 were analyzed as Latin square using the statistical model: $\mathrm{Y}_{\mathrm{ijk}}=\mu+\mathrm{T}_{\mathrm{i}}+\mathrm{P}_{\mathrm{j}}+\mathrm{C}_{\mathrm{k}}+\mathrm{e}_{\mathrm{ijk}}$ where $\mathrm{Y}_{\mathrm{ijk}}$ is the observation, $\mu$ is the overall mean, $\mathrm{T}_{\mathrm{i}}$ is the treatment, $P_{j}$ is the period, $C_{k}$ is the cow, and $e_{i j k}$ is the error term. Mean differences among dietary treatments were tested using the Student-Neuman-Keul's multiple range test (Steele and Torrie, 1980) when treatment differences were identified $(P<0.05)$.

\section{RESULTS AND DISCUSSION}

\section{Experiment 1}

Decreasing the percent of the lactation ration consumed as concentrate from 50 to $20 \%$ of the pre-trial DMI had no effect on percentages of milk fat, protein or SNF. Milk yield, however, decreased 16\% $(P<0.05)$ when concentrate consumption decreased from 35 to $20 \%$ of the DMI (Table 3 ). Increasing the percentage of grass consumed resulted in decreased short chain fatty acids in milk fat (Table 4). Grummer (1991) has re-

Table 4. Milk fatty acid profile, as percentage of total fatty acids, of cows consuming increasing levels of forage (Experiment 1 ).

\begin{tabular}{|c|c|c|c|c|}
\hline \multirow[b]{2}{*}{ Fatty acids } & \multicolumn{3}{|c|}{ Forage (as \% of DMI) } & \multirow[b]{2}{*}{$\mathrm{SE}$} \\
\hline & $50 \%$ & $65 \%$ & $80 \%$ & \\
\hline $\mathrm{C}_{6: 0}$ & 1.12 & 1.11 & 1.01 & 0.03 \\
\hline $\mathrm{C}_{8: 0}$ & $0.70^{\mathrm{a}}$ & $0.68^{a}$ & $0.58^{\mathrm{b}}$ & 0.02 \\
\hline $\mathrm{C}_{10: 0}$ & $1.50^{\mathrm{a}}$ & $1.44^{\mathrm{a}}$ & $1.18^{\mathrm{b}}$ & 0.06 \\
\hline $\mathrm{C}_{12: 0}$ & $1.79^{\mathrm{a}}$ & $1.65^{\mathrm{a}}$ & $1.37^{\mathrm{b}}$ & 0.06 \\
\hline $\mathrm{C}_{14: 0}$ & $7.29^{\mathrm{a}}$ & $6.85^{\mathrm{a}}$ & $6.18^{\mathrm{b}}$ & 0.20 \\
\hline $\mathrm{C}_{14: 1}$ & $0.78^{\mathrm{a}}$ & $0.68^{\mathrm{b}}$ & $0.57^{\mathrm{c}}$ & 0.02 \\
\hline $\mathrm{C}_{15: 0}$ & $0.90^{\mathrm{a}}$ & $0.84^{\mathrm{b}}$ & $0.94^{\mathrm{a}}$ & 0.02 \\
\hline $\mathrm{C}_{16: 0}$ & $24.73^{\mathrm{a}}$ & $24.35^{\mathrm{a}}$ & $23.26^{\mathrm{b}}$ & 0.26 \\
\hline $\mathrm{C}_{16: 1}$ & 1.57 & 1.61 & 1.54 & 0.05 \\
\hline $\mathrm{C}_{17: 0}$ & $0.86^{\mathrm{c}}$ & $0.90^{\mathrm{b}}$ & $1.00^{\mathrm{a}}$ & 0.01 \\
\hline $\mathrm{C}_{18 ; 0}$ & $15.20^{\mathrm{b}}$ & $15.59^{\mathrm{b}}$ & $16.62^{\mathrm{a}}$ & 0.24 \\
\hline $\mathrm{VA}^{\mathrm{i}}$ & $2.46^{\mathrm{c}}$ & $2.75^{\mathrm{b}}$ & $3.47^{\mathrm{a}}$ & 0.15 \\
\hline $\mathrm{C}_{18: 1}$ & 32.98 & 33.45 & 33.47 & 0.55 \\
\hline $\mathrm{C}_{18: 2}$ & 1.91 & 2.15 & 2.03 & 0.08 \\
\hline CLA $^{1}$ & $1.57^{\mathrm{b}}$ & $1.61^{\mathrm{b}}$ & $1.90^{\mathrm{a}}$ & 0.05 \\
\hline $\mathrm{C}_{18: 3}$ & $0.37^{\mathrm{b}}$ & $0.41^{\mathrm{b}}$ & $0.52^{\mathrm{a}}$ & 0.01 \\
\hline
\end{tabular}

ported that long chain unsaturated fatty acids, the predominant fatty acids in the forage (Table 1), can decrease mammary gland synthesis of short chain fatty acids in milk fat.

The proportion of VA in milk fat increased $12 \%(P<$ $0.05)$ when estimated pasture forage intake increased from 50 to $65 \%$ of the diet (Table 4), and VA and CLA increased 26 and $18 \%(P<0.05)$ as the estimated pasture forage intake increased from 65 to $80 \%$ of intake. Linolenic acid is a precursor of VA in the rumen but not CLA (Hartfoot and Hazelwood, 1988). Linoleic acid, an abundant fatty acid in forage (Table 1), is a direct precursor of CLA in the bovine rumen. The VA produced in the rumen is transported to the mammary gland where it can be converted by desaturase enzyme to CLA (Corl et al., 1998; Griinari et al., 2000). The highest milk fat CLA (1.9\%) was attained in the cows consuming $80 \%$ pasture forage. This CLA presumably is formed both directly from rumen $\mathrm{C}_{18: 2}$ and indirectly from $\mathrm{C}_{18: 3}$ converted to VA in the rumen, and subsequently converted to CLA in the mammary gland.

Linolenic acid did not increase in milk fat when the estimated pasture forage consumed by the cows increased from 50 to $65 \%$ of DMI but increased $27 \%(P<$ 0.05 ) when estimated pasture forage intake increased from 65 to $80 \%$ of DMI. Increasing pasture forage at the expense of concentrate, therefore, increases milk CLA and $\mathrm{C}_{18: 3}$; fatty acids shown to have many human health benefits (McGuire et al., 1997; Nettleton, 1991).

\section{Experiment 2}

Dietary treatments. The differences in fatty acid profiles of the three diets mainly reflected the supplemental fat sources since the fat (ether extract) content of hay and fresh cut forage (DM basis) were $0.99 \pm 0.14$ and $1.71 \% \pm 0.33$. The higher content of $\mathrm{C}_{16: 0}$ and $\mathrm{C}_{18: 0}$ in the FFT and HT diets compared to the FFS diet was due to supplementation of these diets with tallow and Alifet. Alifet is a partially hydrogenated tallow and contains $37 \% \mathrm{C}_{18: 0}$ and $27 \% \mathrm{C}_{16: 0}$ (Drackley and Elliott, 1993). The FFS diet had a very high level of linoleic acid (Table 2) due to the fact it was supplemented with solin, which contains $70 \%$ linoleic acid in the oil. Forage contributed linolenic acid to all diets since the main fatty acid in the oil fraction of forage is linolenic acid (Table 1). The higher level of linolenic acid in the solin supplemented diet compared to the FFT and HT diets (Table 2) was due to a high level of linolenic acid (13\%) in solin oil.

Cow performance. Feed intakes for the FFS and FFT diets were similar but were lower than the HT diet (Table 5). The FFS and FFT diets were considerably higher in moisture content than the HT diet (Table 2). 
Table 5. Performance of cows consuming experimental rations (Experiment 2).

\begin{tabular}{lrrrl}
\hline & \multicolumn{3}{c}{ Diets $^{1}$} \\
\cline { 2 - 4 } Item & HT & FFT & FFS & SE \\
\hline Feed intake, kg/d & $20.4^{\mathrm{a}}$ & $14.2^{\mathrm{b}}$ & $14.1^{\mathrm{b}}$ & 0.3 \\
Milk yield, kg/d & $22.9^{\mathrm{a}}$ & $20.0^{\mathrm{b}}$ & $20.0^{\mathrm{b}}$ & 0.7 \\
Milk fat, \% & 3.72 & 3.79 & 3.86 & 0.10 \\
Milk protein, \% & 3.39 & 3.38 & 3.29 & 0.07 \\
Milk SNF, \% & 8.68 & 8.62 & 8.55 & 0.08 \\
\hline
\end{tabular}

${ }^{\mathrm{a}, \mathrm{b}}$ Different letters within rows indicate treatment differences $(P$ $<0.05)$.

${ }^{1} \mathrm{HT}$ = hay supplemented with tallow, FFT = fresh forage supplemented with tallow, and FFS = fresh forage supplemented with ground solin seed.

A decrease in diet DM has been shown to decrease DMI (Lahr et al., 1983), and that may explain the lower DMI of the cows consuming the FFS and FFT diets compared to the HT diet. Other studies have shown that cows consuming increasing levels of fresh forage as pasture have decreased DMI (Kelly et al., 1998b; Dhiman et al., 1999), which may be related to the higher water content of pasture compared to conserved hay. The cows on the FFS and FFT diets were consuming approximately $60 \%$ fresh cut forage with an average diet DM content of $32 \%$ (Table 2). The cows maintained their weight over the course of the experiment in spite of the differences in intake.

Table 6. Very low density lipoprotein fatty acid profile, as percentage of fatty acids (Experiment 2).

\begin{tabular}{lcccc}
\hline & \multicolumn{4}{c}{ Diets $^{1}$} \\
\cline { 2 - 4 } Fatty acids & HT & FFT & FFS & SE \\
\hline $\mathrm{C}_{14: 0}$ & $2.19^{\mathrm{a}}$ & $2.33^{\mathrm{a}}$ & $1.38^{\mathrm{b}}$ & 0.15 \\
$\mathrm{C}_{14: 1}$ & $0.51^{\mathrm{b}}$ & $0.68^{\mathrm{a}}$ & $0.41^{\mathrm{b}}$ & 0.07 \\
$\mathrm{C}_{15: 0}$ & $1.41^{\mathrm{a}}$ & $1.58^{\mathrm{a}}$ & $1.10^{\mathrm{b}}$ & 0.10 \\
$\mathrm{C}_{16: 0}$ & $23.75^{\mathrm{a}}$ & $24.21^{\mathrm{a}}$ & $16.88^{\mathrm{b}}$ & 0.61 \\
$\mathrm{C}_{16: 1}$ & $0.68^{\mathrm{ab}}$ & $0.78^{\mathrm{a}}$ & $0.60^{\mathrm{b}}$ & 0.05 \\
$\mathrm{C}_{17: 0}$ & 2.17 & 2.20 & 1.69 & 0.16 \\
$\mathrm{C}_{18: 0}$ & 36.35 & 36.46 & 40.64 & 1.72 \\
$\mathrm{VA}^{1}$ & $1.85^{\mathrm{b}}$ & $2.16^{\mathrm{b}}$ & $2.71^{\mathrm{a}}$ & 0.22 \\
$\mathrm{C}_{18: 1}$ & 11.99 & 12.01 & 12.41 & 0.80 \\
$\mathrm{C}_{18: 2}$ & 9.27 & 9.30 & 12.25 & 1.05 \\
$\mathrm{CLA}^{2}$ & $0.14^{\mathrm{c}}$ & $0.24^{\mathrm{b}}$ & $0.38^{\mathrm{a}}$ & 0.04 \\
$\mathrm{C}_{18: 3(6)}$ & $0.38^{\mathrm{a}}$ & $0.33^{\mathrm{ab}}$ & $0.24^{\mathrm{b}}$ & 0.04 \\
$\mathrm{C}_{18: 3(3)}$ & 1.86 & 1.63 & 2.10 & 0.51 \\
$\mathrm{C}_{20: 3}$ & 0.19 & 0.18 & 0.15 & 0.03 \\
$\mathrm{C}_{20: 4}$ & $0.77^{\mathrm{a}}$ & $0.62^{\mathrm{ab}}$ & $0.53^{\mathrm{b}}$ & 0.05 \\
$\mathrm{C}_{20: 5}$ & 1.42 & 1.03 & 1.44 & 0.36 \\
$\mathrm{C}_{22: 5}$ & 0.22 & 0.21 & 0.16 & 0.02 \\
$\mathrm{C}_{22: 6}$ & 0.27 & 0.21 & 0.23 & 0.03 \\
\hline
\end{tabular}

${ }^{\mathrm{a}-\mathrm{c}}$ Different letters within rows indicate treatment differences $(P$ $<0.05$ )

${ }^{1} \mathrm{HT}$ = hay supplemented with tallow, FFT = fresh forage supplemented with tallow, and FFS = fresh forage supplemented with ground solin seed.

${ }^{1} \mathrm{VA}=$ vaccenic acid.

${ }^{2} \mathrm{CLA}=$ conjugated linoleic acid $\left(\mathrm{C}_{18: 2}\right.$ cis-9, trans- 11$)$.
Table 7. Low and high density lipoprotein (LHDL) fatty acid profile, as percentage of total fatty acids (Experiment 2).

\begin{tabular}{|c|c|c|c|c|}
\hline \multirow[b]{2}{*}{ Fatty acids } & \multicolumn{3}{|c|}{ Diets $^{1}$} & \multirow[b]{2}{*}{$\mathrm{SE}$} \\
\hline & $\mathrm{HT}$ & FFT & FFS & \\
\hline $\mathrm{C}_{14: 0}$ & $0.43^{\mathrm{a}}$ & $0.41^{\mathrm{a}}$ & $0.32^{\mathrm{b}}$ & 0.03 \\
\hline $\mathrm{C}_{14: 1}$ & $0.59^{\mathrm{a}}$ & $0.56^{\mathrm{a}}$ & $0.43^{\mathrm{b}}$ & 0.04 \\
\hline $\mathrm{C}_{15: 0}$ & 0.45 & 0.44 & 0.40 & 0.02 \\
\hline $\mathrm{C}_{16: 0}$ & $9.67^{\mathrm{a}}$ & $10.04^{\mathrm{a}}$ & $9.10^{\mathrm{b}}$ & 0.19 \\
\hline $\mathrm{C}_{16.1}$ & $1.22^{\mathrm{a}}$ & $1.28^{\mathrm{a}}$ & $0.89^{\mathrm{b}}$ & 0.06 \\
\hline $\mathrm{C}_{17: 0}$ & $1.93^{\mathrm{b}}$ & $2.41^{\mathrm{a}}$ & $2.40^{\mathrm{a}}$ & 0.12 \\
\hline $\mathrm{C}_{18: 0}$ & 15.71 & 15.08 & 15.35 & 0.28 \\
\hline $\mathrm{VA}^{2}$ & $0.36^{\mathrm{b}}$ & $0.40^{\mathrm{b}}$ & $0.48^{\mathrm{a}}$ & 0.02 \\
\hline $\mathrm{C}_{18 \cdot 1}$ & $10.94^{\mathrm{a}}$ & $11.86^{\mathrm{a}}$ & $8.00^{\mathrm{b}}$ & 0.37 \\
\hline $\mathrm{C}_{18.2}$ & $42.25^{\mathrm{b}}$ & $41.72^{\mathrm{b}}$ & $49.33^{\mathrm{a}}$ & 0.95 \\
\hline $\mathrm{CLA}^{3}$ & $0.12^{\mathrm{b}}$ & $0.15^{\mathrm{ab}}$ & $0.18^{\mathrm{a}}$ & 0.02 \\
\hline $\mathrm{C}_{18: 3(6)}$ & 1.41 & 1.37 & 1.15 & 0.10 \\
\hline $\mathrm{C}_{18: 3(3)}$ & $7.67^{\mathrm{a}}$ & $6.75^{\mathrm{b}}$ & $4.81^{\mathrm{c}}$ & 0.34 \\
\hline $\mathrm{C}_{20: 3}$ & 2.32 & 2.15 & 2.02 & 0.13 \\
\hline $\mathrm{C}_{20: 4}$ & 2.59 & 2.84 & 2.85 & 0.14 \\
\hline $\mathrm{C}_{20: 5}$ & 0.95 & 0.93 & 0.89 & 0.06 \\
\hline $\mathrm{C}_{22: 5}$ & 0.42 & 0.44 & 0.46 & 0.02 \\
\hline $\mathrm{C}_{22: 6}$ & $0.12^{\mathrm{b}}$ & $0.15^{\mathrm{a}}$ & $0.17^{\mathrm{a}}$ & 0.01 \\
\hline
\end{tabular}

Average milk yield of the cows consuming the FFT diet was $13 \%(P<0.05$; Table 5$)$ lower than the milk yields of the cows consuming the HT diet. The cows consuming the FFS diet consumed the same amount of feed and had similar milk yield $(P>0.05)$ as the cows consuming the FFT diet. The percentage of milk fat, protein, and SNF values were similar across all diets.

Plasma fatty acids. The proportions of $\mathrm{C}_{14: 0}$, and $\mathrm{C}_{16: 0}$ were similar $(P>0.05)$ in the VLDL and LHDL fractions of the plasma for cows consuming the FFT and HT diets (Tables 6 and 7), consistent with approximately equal dietary levels of these fatty acids. The proportions of $\mathrm{C}_{14: 0}$, and $\mathrm{C}_{16: 0}$ were higher in the plasma VLDL fraction compared to the LHDL fraction (Tables 6 and 7). Forage type and fat source had no effect on $\mathrm{C}_{18: 0}$ VLDL or LHDL levels. The proportion of $\mathrm{C}_{18: 0}$ of the total fatty acids, however, was much higher in the VLDL than in the LHDL plasma fraction. The cows consuming the FFS diet had lower plasma VLDL levels of $\mathrm{C}_{14: 0}(41$ and $37 \% ; P<0.05)$ and $\mathrm{C}_{16: 0}(30$ and $29 \%$; $P<0.05$ ) compared to cows consuming the FFT and the HT diets.

The level of $\mathrm{C}_{18: 2}$ in the FFS diet was approximately five times the level in the FFT and HT diets (Table 2). This fatty acid is located mainly as a cholesterol ester in the high density lipoprotein (HDL) fraction of plasma (Christie, 1981). The bovine plasma HDL fraction is 
known to have a relatively slow turn over rate, and $\mathrm{C}_{18: 2}$ is conserved in this fraction for use in membrane structure and function (Noble 1981). Plasma levels, therefore, do not normally reflect dietary levels (Christie, 1981). Linoleic acid was $18 \%(P<0.05)$ higher in the LHDL fraction of cows consuming the FFS compared to the FFT diet (Table 7), indicating that higher dietary levels for this fatty acid were reflected in plasma levels.

The majority of plasma $\mathrm{C}_{18: 3}$ was in the LHDL fraction of the plasma. The proportion of $\mathrm{C}_{18: 3}$ in the plasma HLDL fraction of the FFT diet was $12 \%(P<0.05)$ lower compared to the HT diet. This fatty acid was also $29 \%$ lower in the LHDL fraction of the cows consuming the FFS diet compared to the FFT diet even though the level of $\mathrm{C}_{18: 3}$ in the FFS diet was $45 \%$ higher than the FFT diet.

The proportions of VA and CLA were 5.1 to 5.6 and 1.2 to 2.1 fold higher in the plasma VLDL fraction compared to the LHDL fraction of the cows on the three experimental diets. This is consistent with the fact that the VLDL fraction supplies the mammary gland with fatty acids (Christie, 1981), and milk fat contains relatively high concentrations of VA and CLA. There is evidence of selective uptake of triglycerides, rich in stearic acid, by the mammary gland (Christie, 1981). There is no evidence, however, that there is differential uptake of VA and CLA. Calculation of the percent endogenous synthesis of CLA from VA, based on the presumption of similar absorption, results in values of 69 , 79 , and $87 \%$ for the FFS, FFT, and HT diets. The value for the FFS diet is close to the value Griinari et al. (2000), determined by mammary gland enzyme inhibition studies, of $65 \%$ endogenous synthesis. The differences in the percentage of endogenous CLA would indicate that the percentage of endogenous milk fatty acid decreases as the diet changes from the HT to the FFT and to the FFS diet. This may be due to an increase in the level of linoleic acid available to the rumen, forming CLA that is directly transported to the mammary gland as CLA. In the case of the cows consuming the FFS diet, this increase would be due to the crushed solin. In the case of the FFT diet, the fresh forage may have a higher available level of linoleic acid than the conserved hay in the HT diet. The cows consuming the HT diet, compared to those consuming the FFT diet, had a higher ratio of VA:CLA in the plasma VLDL (13:1 compared to 9:1). Relatively more VA than CLA was produced in and/or escaped from the rumen of the cows consuming the HT as compared to the FFT diet. This may indicate that linolenic acid (the predominate fatty acid in forage) may play a greater role in VA production in the HT compared to the FFT fed cows since linolenic acid can form VA but not CLA, whereas linoleic acid can form both (Harfoot and Hazelwood, 1988). Feeding
Table 8. Milk fatty acid profile, as percentage of total fatty acids (Experiment 2).

\begin{tabular}{lrrrr}
\hline & \multicolumn{4}{c}{ Diets $^{1}$} \\
\cline { 2 - 4 } Fatty acids & HT & FFT & FFS & SE \\
\hline $\mathrm{C}_{6: 0}$ & $0.98^{\mathrm{a}}$ & $0.95^{\mathrm{a}}$ & $0.83^{\mathrm{b}}$ & 0.03 \\
$\mathrm{C}_{8: 0}$ & $0.63^{\mathrm{a}}$ & $0.59^{\mathrm{b}}$ & $0.53^{\mathrm{c}}$ & 0.02 \\
$\mathrm{C}_{10: 0}$ & $1.36^{\mathrm{a}}$ & $1.26^{\mathrm{b}}$ & $1.16^{\mathrm{c}}$ & 0.05 \\
$\mathrm{C}_{12: 0}$ & $1.69^{\mathrm{a}}$ & $1.53^{\mathrm{b}}$ & $1.44^{\mathrm{c}}$ & 0.05 \\
$\mathrm{C}_{14: 0}$ & $8.05^{\mathrm{a}}$ & $7.28^{\mathrm{b}}$ & $6.48^{\mathrm{c}}$ & 0.18 \\
$\mathrm{C}_{14: 1}$ & $0.89^{\mathrm{a}}$ & $0.83^{\mathrm{b}}$ & $0.57^{\mathrm{c}}$ & 0.03 \\
$\mathrm{C}_{15: 0}$ & $1.09^{\mathrm{a}}$ & $0.97^{\mathrm{b}}$ & $0.85^{\mathrm{c}}$ & 0.02 \\
$\mathrm{C}_{16: 0}$ & $28.09^{\mathrm{a}}$ & $27.37^{\mathrm{b}}$ & $20.97^{\mathrm{c}}$ & 0.30 \\
$\mathrm{C}_{16: 1}$ & $2.01^{\mathrm{b}}$ & $2.10^{\mathrm{a}}$ & $1.40^{\mathrm{c}}$ & 0.08 \\
$\mathrm{C}_{18: 0}$ & $14.48^{\mathrm{b}}$ & $14.92^{\mathrm{b}}$ & $19.88^{\mathrm{a}}$ & 0.55 \\
$\mathrm{VA}^{2}$ & $1.65^{\mathrm{c}}$ & $2.02^{\mathrm{b}}$ & $2.83^{\mathrm{a}}$ & 0.18 \\
$\mathrm{C}_{18: 1}$ & $32.53^{\mathrm{c}}$ & $33.49^{\mathrm{b}}$ & $35.45^{\mathrm{a}}$ & 0.45 \\
$\mathrm{C}_{18: 2}$ & $1.56^{\mathrm{c}}$ & $1.72^{\mathrm{b}}$ & $2.86^{\mathrm{a}}$ & 0.07 \\
$\mathrm{CLA}^{3}$ & $0.93^{\mathrm{c}}$ & $1.07^{\mathrm{b}}$ & $1.30^{\mathrm{a}}$ & 0.04 \\
$\mathrm{C}_{18: 3}$ & $0.29^{\mathrm{a}}$ & $0.25^{\mathrm{b}}$ & $0.25^{\mathrm{b}}$ & 0.01 \\
\hline
\end{tabular}

${ }^{\mathrm{a}, \mathrm{b}, \mathrm{c}}$ Different letters within rows between columns indicate treatment differences $(P<0.05)$.

${ }^{1} \mathrm{HT}=$ hay supplemented with tallow, FFT $=$ fresh forage supplemented with tallow, and FFS = fresh forage supplemented with ground solin seed.

${ }^{2} \mathrm{VA}=$ vaccenic acid.

${ }^{3} \mathrm{CLA}=$ conjugated linoleic acid $\left(\mathrm{C}_{18: 2}\right.$ cis-9, trans- 11$)$.

the FFS diet compared to the FFT diet increased plasma VLDL CLA and VA by $58 \%(P<0.05)$ and $25 \%(P<$ $0.1)$. The ratio of VA:CLA in the VLDL of the cows consuming the FFS diet was 7:1, which was lower than the plasma VLDL ratios for both the cows consuming the FFT and HT diets. This would indicate a relatively faster production of rumen CLA than VA by cows consuming the FFS diet compared to the cows consuming the FFT and especially the HT diets. This tendency could be due to the higher levels of CLA precursor $\left(\mathrm{C}_{18: 2}\right)$ in the rumen from the solin supplemented in the FFS diet. If there is tendency for rumen escape of CLA to increase relatively faster than VA when the dietary level of $\mathrm{C}_{18: 2}$ increases, a greater percentage of milk CLA may originate directly from rumen CLA as linoleic acid increases in the diet. Further studies are needed to determine if the precursor of milk CLA differs under different dietary conditions.

Milk fatty acids. The cows consuming the FFT lactation diet had lower proportions of milk $\mathrm{C}_{8: 0}, \mathrm{C}_{10: 0}, \mathrm{C}_{12: 0}$, $\mathrm{C}_{14: 0}, \mathrm{C}_{14: 1}, \mathrm{C}_{15: 0}$, and $\mathrm{C}_{16: 0}$, compared to the HT diet (Table 8). These fatty acids are synthesized endogenously and do not depend on dietary levels. Components in fresh forage therefore, must affect endogenous synthesis of these fatty acids. The cows consuming the FFS lactation diet had lower proportions of milk fatty acids $\mathrm{C}_{6: 0}, \mathrm{C}_{8: 0}, \mathrm{C}_{10: 0}, \mathrm{C}_{12: 0}, \mathrm{C}_{14: 0}, \mathrm{C}_{14: 1}, \mathrm{C}_{15: 0}, \mathrm{C}_{16: 0}$, and $\mathrm{C}_{16: 1}$ compared to the FFT diet (Table 8). The lower proportions of the milk fat fatty acids $\mathrm{C}_{6: 0}$ to $\mathrm{C}_{14: 1}$ may be due to reduced mammary gland lipogenesis which may be 
caused by increasing levels of $\mathrm{C}_{18: 2}$ (Palmquist et al., 1993; Hermanse, 1995). It has been demonstrated that CLA affects the stearoyl-CoA desaturase activity in mouse liver by decreasing the expression of the stearoyl-CoA desaturase mRNA and could have an effect on the same enzyme in the mammary gland (Ntambi et al., 1999) resulting in decreased synthesis of the short chain fatty acids. This effect on the stearoyl-CoA desaturase mRNA however, is thought to be caused by the trans-10, cis-12 CLA isomer that is found in commercial CLA preparations but was not detected in the plasma VLDL fraction or in milk fat in the present experiment. Therefore, it does not seem likely that the increased cis-9, trans-11 CLA is affecting the mammary gland synthesis of the short chain fatty acids.

The proportion of VA and CLA increased in milk fatty acids by 22 and $15 \%(P<0.05)$ when the cows consumed the FFT diet compared to the HT diet. These differences are consistent with differences observed when pasture is consumed compared to feeding grass-legume hay (Dhiman et al., 1999; Kelly et al., 1998b). The level of VA and CLA increased 40 and $21 \%(P<0.05)$ in the milk fat of the cows consuming the FFS diet compared to the FFT diet. The high level of linoleic acid supplied by ground solin seed to the FFS diet was responsible for these latter increases (Kelly et al., 1998a). The $\mathrm{C}_{18: 2}$ from the solin may act both as precursor of CLA and VA and may block the saturation of VA to stearic acid (Noble et al., 1974). This indicates that high VA and CLA levels, produced by feeding fresh forage, can be further increased by supplemental oilseed (high in linoleic acid).

The cows consuming the FFS diet, which had a low level of $\mathrm{C}_{18: 0}$ (Table 2), had a higher milk fat level of this fatty acid $(P<0.05)$ than the cows consuming the FFT and HT diets which were high in $\mathrm{C}_{18: 0}$. Rumen biohydrogenation of $\mathrm{C}_{18: 2}$, which would be abundant in the rumen of the cows consuming the FFS diet, would result in $\mathrm{C}_{18: 0}$ (Harfoot and Hazelwood, 1988) and would account for the high VLDL level of $\mathrm{C}_{18: 0}$ in the cows consuming this diet.

The proportion of $\mathrm{C}_{18: 2}$ was $10 \%$ higher $(P<0.05)$ in the milk fat of the cows fed the FFT diet compared to the HT diet. This would indicate a higher level of $\mathrm{C}_{18: 2}$ escaping from the rumen due to high rumen $\mathrm{C}_{18: 2}$ levels. High rumen $\mathrm{C}_{18: 2}$ levels is consistent with the high plasma VLDL and milk fat VA and CLA levels in the cows consuming the FFT diet. The proportion of $\mathrm{C}_{18: 2}$ was $66 \%$ higher $(P<0.05)$ in the milk fat of the cows fed the FFS diet compared to the FFT diet. This again would indicate a higher level of $\mathrm{C}_{18: 2}$ escaping from the rumen; the result of high $\mathrm{C}_{18: 2}$ levels in the rumen of the cows consuming the FFS diet compared to the FFT diet. This is reflected in the high plasma VLDL and milk fat VA and CLA levels of these cows.

Milk fat levels of $\mathrm{C}_{18: 3}$ were very similar across all three diets with a slight increase in the cows consuming the hay diet. Haug et al. (2001) reported increased levels of milk $\mathrm{C}_{18: 3}$ feeding hay compared to fresh grass and silage, all from the same grass forage. Rumen levels of $\mathrm{C}_{18: 3}$ should be higher in cows consuming the FFS diet compared to the FFT and HT diets (Table 2) and more $\mathrm{C}_{18: 3}$ would have been expected to escape rumen biohydrogenation and be transported to the milk. It may be that high levels of $\mathrm{C}_{18: 2}$ in the rumen of the cows consuming the FFS diet interfered with the escape and/or transport of $\mathrm{C}_{18: 3}$ or the rumen biohydrogenation of the $\mathrm{C}_{18: 3}$ was more efficient in the cows consuming the FFS diet.

\section{CONCLUSIONS}

Increasing the level of fresh forage fed to dairy cows by increasing the percent of the diet consumed as pasture or fresh chop increased the milk fat levels of VA, CLA, and $\mathrm{C}_{18: 3}$. Offering grass forage at $80 \%$ of intake is needed to attain relatively high CLA levels (1.9\% of milk fat). Feeding cows fresh cut forage compared to conserved hay increased plasma VLDL and milk fat proportions of VA and CLA. Supplementing linoleic acid (solin) with fresh forage increased plasma VLDL and milk fat proportions of VA and CLA further than was accomplished by switching the forage from hay to fresh chop.

\section{ACKNOWLEDGMENTS}

This research was funded by the Dairy Farmers of Canada, the Natural Sciences and Engineering and Research Council of Canada, and by the Canada-Manitoba Agri-Food Research Development Initiative. United Grain Growers provided financial support and supplied oilseeds used in the experiments. The technical assistance of Ms. Terri Garner and the Glenlea Research Station staff was appreciated.

\section{REFERENCES}

Association of Official Analytical Chemists. 1990. Official Methods of Analysis. 15th ed. AOAC, Washington, DC.

Canadian Council on Animal Care. 1993. Guide to the care and use of experimental animals. E. D. Olfert, B. M. Cross, and A. A. McWilliam ed. Vol 1, 2nd ed. CCAC, Ottawa, ON.

Christie, W. W., 1981. The effects of diet and other factors on the lipid composition of ruminant tissues and milk. Pages 193-226 in Lipid Metabolism in Ruminant Animals. Ed. W. W. Christie, Pergamon Press, Oxford, England.

Corl, B. A., P. Y. Chouinard, D. A. Dwyer, D. E. Bauman, J. M. Griinari, and K. V. Nurmela. 1998. Conjugated linoleic acid in milk fat of dairy cows originates in part by endogenous 
synthesis from trans-11 octadecenoic acid. J. Dairy Sci. 81 (Suppl.1):233(Abstr.).

Dhiman, T. R., G. R. Anand, L. D. Satter, and M. W. Pariza. 1999. Conjugated linoleic acid content of milk from cows fed different diets. J. Dairy Sci. 82:2146-2156.

Drackley, J. K., and J. P. Elliot. 1993. Milk composition, ruminal characteristics and nutrient utilization in dairy cows fed partially hydrogenated tallow. J. Dairy Sci. 76:183-196.

Dribnenski, J. C. P., S. F. McEachen, A. G. Green, E. O. Kenaschuk, and K. Y. Rashid. 1999. Linola '1084' low-linolenic acid flax. Can. J. Plant Sci. 79:607-609.

Folch, J., M. Lees, and G. H. Sloane-Stanley. 1957. A simple method for the isolation and purification of total lipids from animal tissues. J. Biol. Chem. 226:497-509.

Goering, H. K., and P. J. VanSoest. 1970. Forage fiber analyses. Agric. Handbook No. 379. ARS-USDA, Washington, DC.

Griinari, J. M., and D. E. Bauman. 1999. Biosynthesis of conjugated linoleic acid and its incorporation into meat and milk in ruminants. Pages 180-200 in Advances in Conjugated Linoleic Acid Research. M. P. Yuraweza, M .M. Mossoba, J. K. G. Kramer, G. Nelson, and M. W. Piriza, ed. AOAC Press, Champaign, IL.

Griinari, J. M., B. A. Corl, S. H. Lacy, P. Y. Chouinard, K. V. Nurmela, and D. E. Bauman. 2000. Conjugated linoleic acid is synthesized endogenously in lactating dairy cows by $\in{ }^{9} 9$-desaturase. J. Nutr. 130:2285-2291.

Grummer, R. R.1991. Effect of feed on the composition of milk fat. J. Dairy Sci. 74:3244-3257.

Harfoot C. G., and G. P. Hazelwood 1988. Lipid metabolism in the rumen. Pages 285-322 in The Rumen Microbial Ecosystem. ed P. N. Hobson, Elsevier Science Publishers, London.

Haug, A., A. S. Kvam, A. T. Randby, P. Linstad, and O. M. Harstad. 2001. Effect of conservation method for grass crops on the fatty acid composition of milk. (Abstr.) Page 40 in Proc. 1st Int. Conf. Conjugated Linoleic Acid (CLA), Ålesund, Norway.

Hermanse, J. E. 1995. Prediction of milk fatty acid profile in dairy cows fed dietary fat differing in fatty acid composition. J. Dairy Sci. 78:872-879.

Kelly, M. L., J. R. Berry, A. D. Dwyer, J. M. Griinari, P. Y. Chouinard, M. E. Van Amburgh, and D. E. Bauman. 1998a. Dietary fatty acid sources affect conjugated linoleic acid concentrations in milk from lactating dairy cows. J. Nutr. 128:881-885.

Kelly, M. L., E. S. Kolver, D. E. Bauman, M. E. Van Amburg, and L. D. Muller. 1998b. Effect of intake of pasture on concentrations of conjugated linoleic acid in milk of lactating dairy cows. J. Dairy Sci. 81:1630-1636.

Kramer J. K. G., J. Zhou, J. Zhang, M. E. R. Dugan, and J. L. Aalhus. 2001. Differences in CLA incorporation into different tissues and lipid classes of pigs fed a diet containing either a 2 or 4 CLA isomer mixture. (Abstr.) Page 38 in Proc. 1st Int. Conf. Conjugated Linoleic Acid (CLA), Ålesund, Norway

Lahr, D. A., D. E. Otterby, D. G. Johnson, J. G. Linn, and R. G. Lundquist. 1983. Effects of moisture content of complete diets on feed intake and milk production by cows. J. Dairy Sci. 66:1891-1900.

McGuire, M. A., M. K. McGuire, and M. S. McQuire. 1997. Bovinic acid: The natural CLA. Pages 217-226 in Proc. Cornell Nutr. Conf. Feed Manuf., Cornell Univ., Ithaca, NY.

Nettleton, J. A. 1991. Omega-3 fatty acids: Comparison of plant and seafood sources in human nutrition. J. Am. Diet Assoc. 91:331-337.

Noble, R. C., J. H. Moore, and C. G. Harfoot. 1974. Observations on the pattern of biohydrogenation of esterified and unesterified linoleic acid in the rumen. Br. J. Nutr. 31:99-108.

Ntambi, J. M. , Y. Choi, and Y. Kim. 1999. Regulation of StearoylCoA by conjugated linoleic acid in Advances in Conjugated Linoleic Acid Research vol. 1. M. P. Yurawecz, M. M. Mossoba, J. K. G. Kramer, M. W. Piraza, and G. J. Nelson, ed. AOCS press, Champaign, IL.

Statistical Analysis Systems Inc., 1996. SAS; Statistic's Version 6.12 Edition. SAS Institute Inc., Cary, NC.

Palmquist, D. L., A. D. Beaulieu, and D. M. Barbano. 1993. Feeds and animal factors influencing milk fat composition. J. Dairy Sci. 76:1753-1771.

Steele, R. G. D., and J. H. Torrie 1980. Principles and Procedures of Statistics. A Biomedical Approach, 2nd ed. McGraw-Hill Publ. Co.

Wolff, R. L., D. Precht, and J. Molkentin. 1989. Occurrence and distribution profiles of trans-18:1 acids in edible fats of natural origin in Trans Fatty Acids in Human Nutrition. J. L. Sebedio and W. W. Christie, ed. The Oily Press, Scotland. 